\title{
NOTES ON THE SYNONYMY OF THE SPECIES OF ERAX OF THE EASTERN UNITED STATES.
}

BY CHARLES W. JOHNSON, BOSTON, MASS.

IN most catalogues of insects there are some names in use which we know should be changed. This fact is brought forcibly to our minds in preparing faunal lists, and that such names should no longer be used is evident; a faunal list, however, is no place for such changes, which often require some elucidation. That the present names in use for the common species of the genus Erax are misapplied, is evident to all systematic dipterologists. Working on three faunal lists has compelled me to take up this matter, for it does not seem desirable to continue to perpetuate these discrepancies. While the following synonymy has been largely intimated by Baron Osten Sacken, and Dr. Williston, authors have failed to realize its significance.

\section{Erax aestuans (Linné).}

Asilus aestuans Linné, Syst. Nat., 12 ed. 1007, 1767.

Dasypogon aestuans Fabr., Syst. Antl. p. 164, 1805.

Asilus macrolabis Wied., Auss. Zw. Ins., I, 458, 1828.

Asilus aestuans Macq., Hist. Nat. Dipt., I, 312, 1834.

Erax femoratus Macq., Dipt. Exot., I pt. 2, p. 115, 1839 (.ð.).

Erax incisuralis Macq., Dipt. Exot., I, pt. 2, p. 117, 1839 (ㅇ ).

Erax bastardi Macq., Dipt. Exot., I, pt. 2, p. 117, pl. 9, f. 7, 1839 (ð 우).

Erax tibialis Macq., Dipt. Exot., I, pt. 2, p. 118, 1839 우.

This is the most common and variable of the eastern species of Erax. It is on the other hand the only one with three white abdominal segments, therefore, it seems that the brief description of Linné can only apply to this species: "cinereus abdominis ultimis tribus segmentis albis. Habitat Pennsylvania." The number of white segments, however, varies from three to four, the latter representing the $A$. macrolabis of Wiedemann. If this was constant its specific standing might not be questioned, but among the specimens before me are many intermediates in which the dorsal portion of the fourth segment is blackish leaving very broad posterior and lateral margins of white. As to Macquart's species there seems to be no question as to the synonymy. 
Erax RUfibarbis (Macquart).

Asilus aestuans Wiedemann, Dipt. Exot. p. 200, 1820 (non Linné).

Erax rufibarbis Macq., Dipt. Exot., I, pt. 2, 116, 1839.

The $A$. aestuans of Wiedemann is a very different species from what Linné described. "Rubido-fuscus, $* *$ barba et vibrissae rufo-flavicantes, $* *$ mare abdominis segmentis duabus penultimis albis" seem only referable to the species common in late summer and early autumn, and later described by Macquart as E. rufibarbis: "Mystace rufo. Abdominis segmentis duobus apicalibus albis." Macquart noticed the discrepancy between Linné's and Wiedemann's description (Hist. Nat. Dipt., I, 312,1834 ) and described Linné's species, but in 1838 (Dipt. Exot., I, pt. 2) he seems to have forgotten or ignored the fact and gives Wiedemann's description of E. aestuans on page 115 and on page 116 describes his E. rufibarbis. Since Dr. Williston in 1885 (Trans. Amer. Ent. Soc., XII, 72) referred to the above synonymy, there has been no change. As Wiedemann's name cannot be used, we are obliged to adopt the one given by Macquart.

\section{Erax albibarbis Macquart.}

E. albibarbis Macq., Dipt. Exot., I, pt. 2, 118, 1838.

E. cinerescens Bellardi, Saggio Ditt. Mess., pt. II, 39, pl. 2, f. 10, 1861.

E. furax Williston, Trans. Amer. Ent. Soc., XII, 67, 1885.

There seems to be no doubt regarding the synonymy of this common and widely distributed species, and Macquart's name will have to be adopted.

Erax interruptus (Macquart).

Asilus interruptus Macq., Hist. Nat. Dipt., II, 310, 1834.

Erax maculatus Macq., Dipt. Exot., I, pt. 2, II, pl. 9, f. 6, 1838.

Erax lateralis Macq., Dipt. Exot., I, pt. 2, 116, 1838.

Erax ambiguus Macq., Dipt. Exot., Suppl. 1, 84, 1846.

Erax (Eristicus) villosus 'Bellardi, Saggio, Ditt. Mess., pt. II, 49, 1861.

Neoeristicus villosus (Bellardi) Osten Sacken, Cat. Dipt. N. A., 1878, p. 81, (Note 129, p. 235. Eristicus preocecupied).

The above synonymy is practically that given by Osten Sacken. After a careful study of the descriptions Macquart's oldest name has been given precedence. 

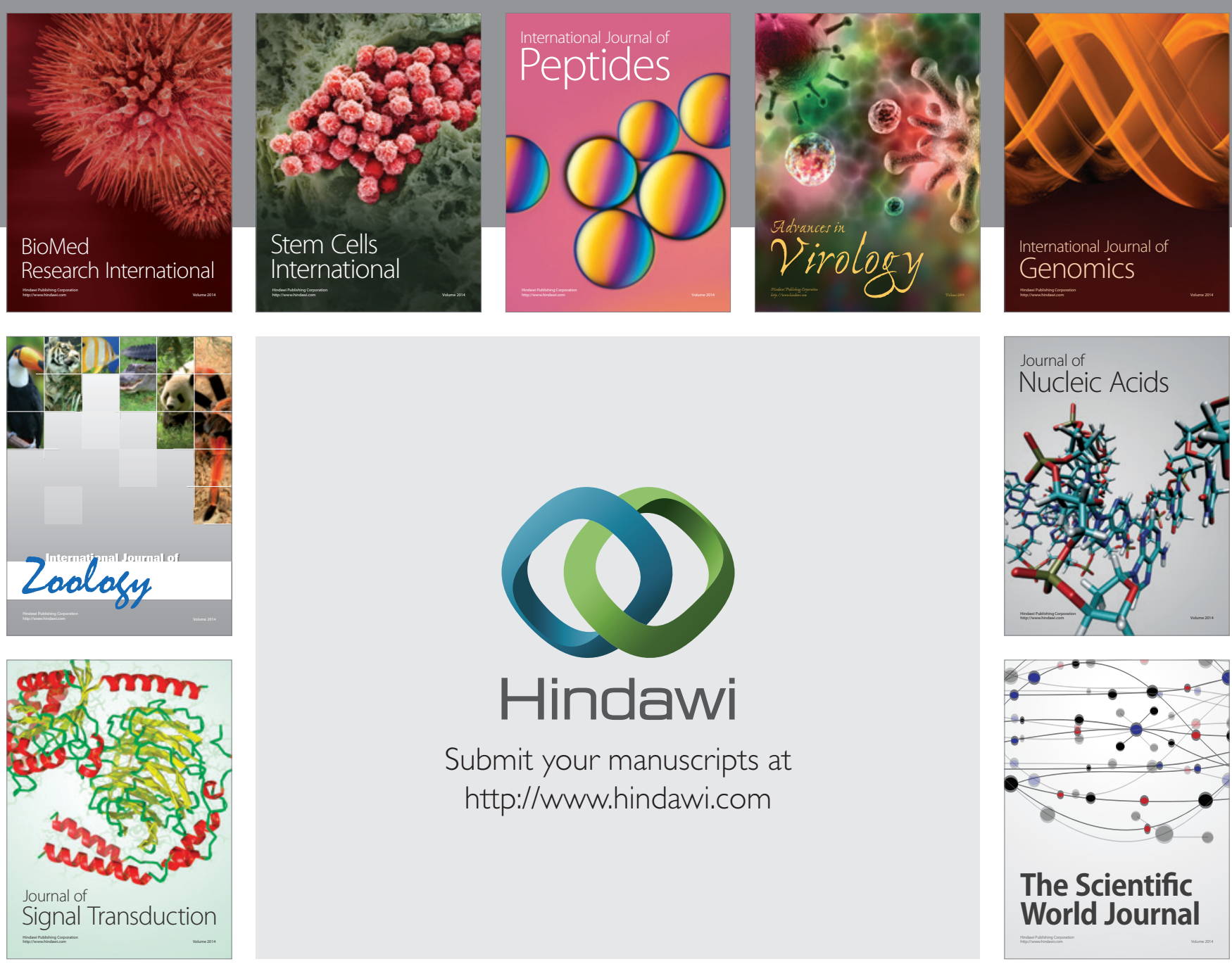

Submit your manuscripts at

http://www.hindawi.com
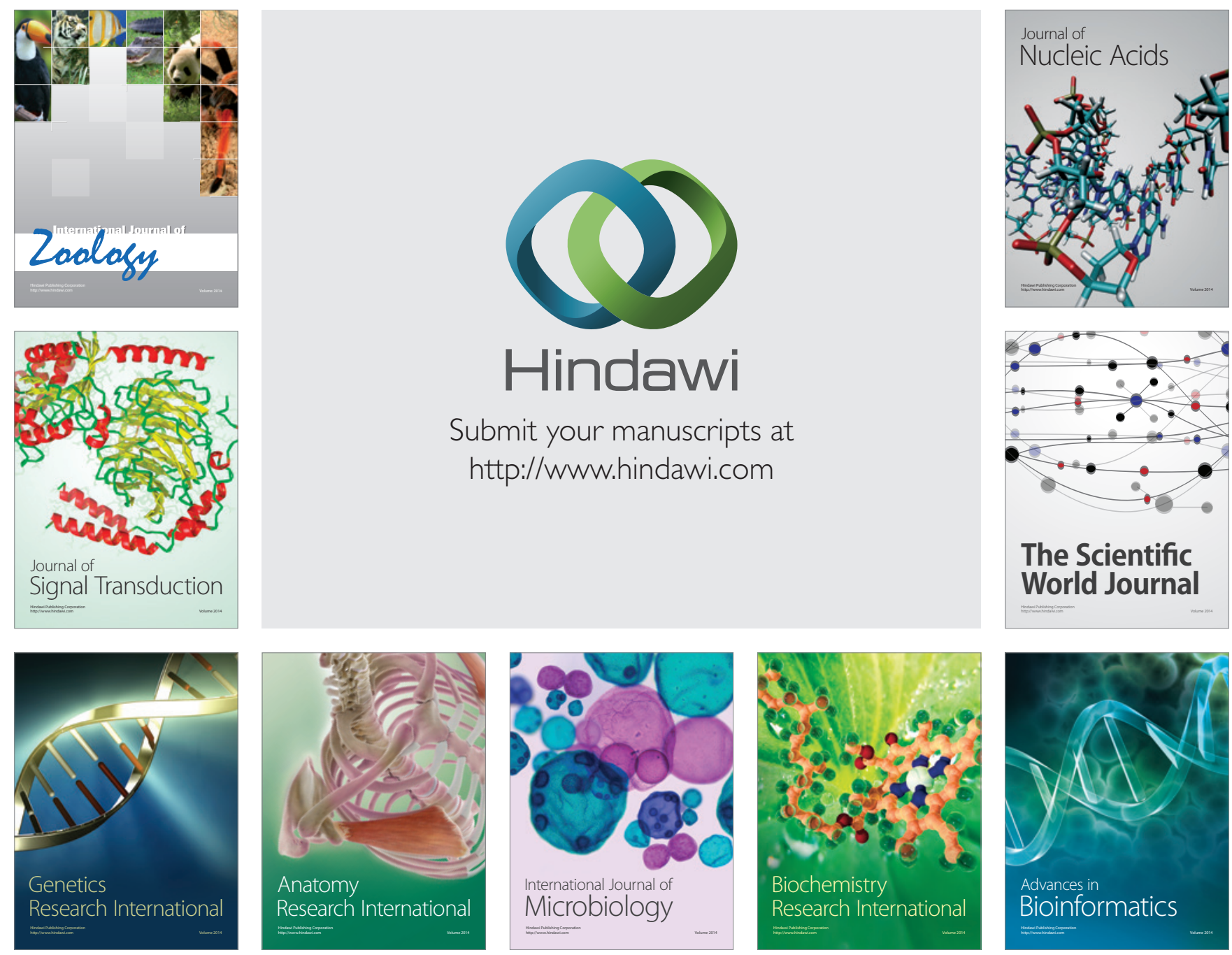

The Scientific World Journal
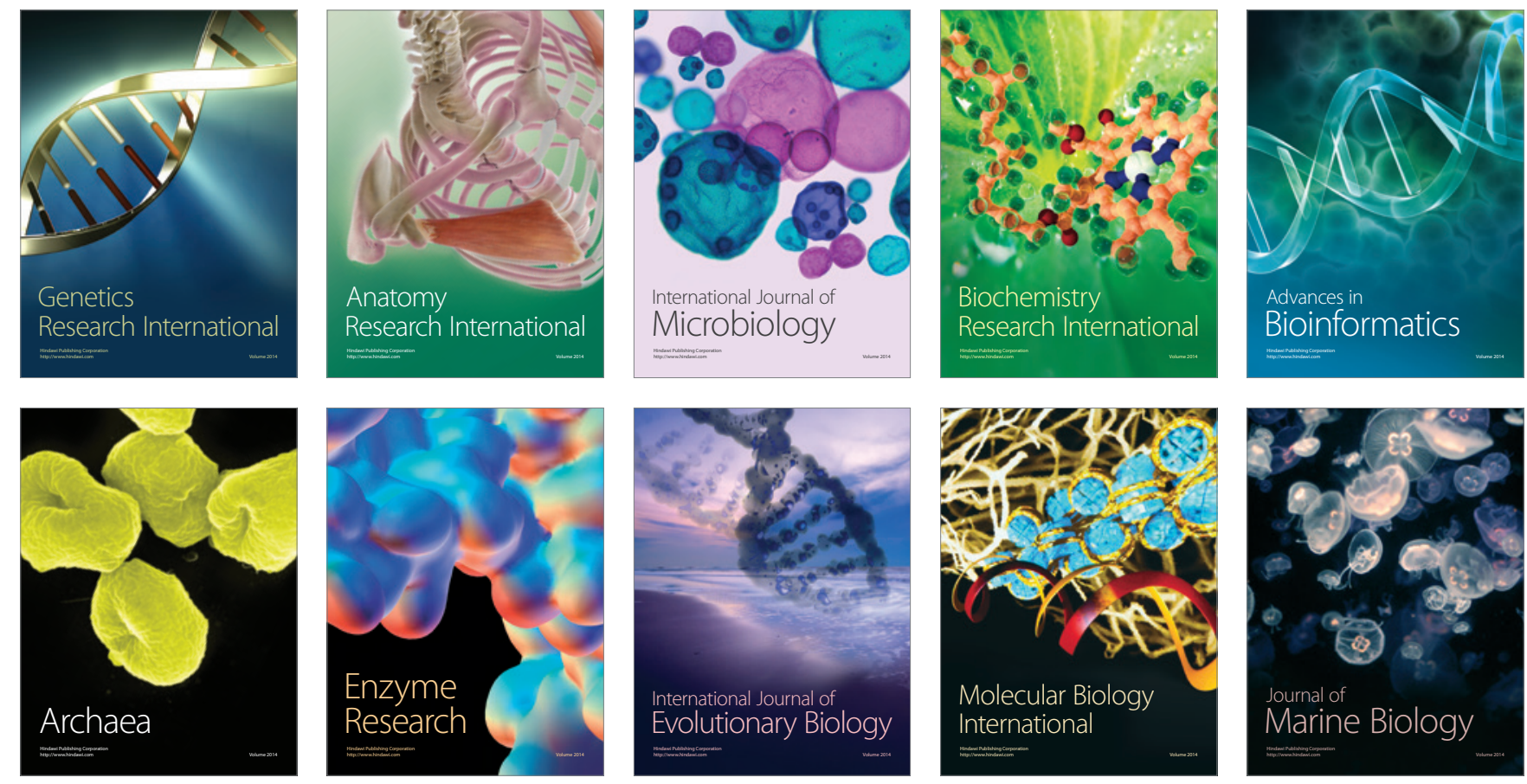